\title{
Okul öncesi dönem çocuklarının saldırganlık yönelimleri ile annelerinin ilgi düzeylerinin belirlenmesi
}

\section{Determination of aggression tendencies preschool children and their mothers' level of interest}

\section{Makale Geçmişi \\ Geliş : : 19 Nisan 2019 \\ Düzeltme : 19 Temmuz 2019 \\ Kabul : 20 Ağustos 2019}

\section{Makale Türü}

Araştırma Makalesi

\section{Article History}

Received : 19 April 2019

Revised : 19 July 2019

Accepted : 20 August 2019

\section{Article Type}

Research Article

\author{
Necla Tuzcuoğlu ${ }^{1}$, Özge Cengiz², Gülşen İlçi Küsmüş ${ }^{3}$
}

Öz: Bu araștırmanın genel amacı, okul öncesi dönem çocuklarının saldırganlık yönelimleri ile annelerinin ilgi düzeyleri arasındaki ilişkinin tespit edilmesidir. Ayrıca okul öncesi dönem çocuklarının saldırganlık yönelimleri ile annelerinin ilgi düzeyleri cinsiyet, çocuğun yaşı, kardeş sayısı, doğum sırası, anne yaş1, anne öğrenim durumu, anne çalışma durumu değişkenleri açısından incelenmiştir. Araştırma, nicel araştırma yöntemlerinden biri olan ilișki tarama modeli ile yürütülmüștür. Araștırmanın çalıșma grubunu 20182019 eğitim ve öğretim yılında İstanbul ilinde okul öncesi eğitim kurumlarına devam etmekte olan 218 çocuk ve bu çocukların anneleri oluşturmaktadır. Okul öncesi dönem çocuklarının saldırganlık yönelim düzeyleri ortalamanın altında; annelerinin ilgi düzeyleri ortalamanın üzerindedir. Çocukların saldırganlık yönelimleri ile anne ilgileri arasında düşük düzeyde ve negatif yönde anlamlı bir ilişki bulunmuştur.

Anahtar Kelimeler: Okul Öncesi Dönem, Saldırganlık, Saldırganlık Yönelimi, Anne İlgisi

Abstract: The general purpose of this study is to determine the relationship between the aggression tendencies of preschool age children and levels of interest of their mothers. In addition, the aggression tendencies of preschool age children and their mothers' levels of interest were examined in terms of gender, age of the child, number of siblings, birth order, maternal age, maternal education status and maternal working status. The research was carried out with the relationship scanning model which is one of the quantitative research methods. The study group consisted of 218 children and their mothers attending preschool education institutions in Istanbul in the 2018-2019 academic year. The levels of aggression of preschool children are below average; mothers' level of interest is above average. A significant and negative correlation was found between the aggression tendencies of the children and their mother's interests.

Keywords: Preschool Period, Aggression, Aggression Tendency, Interest of Mother

\footnotetext{
${ }^{1}$ Marmara Üniversitesi, Atatürk Eğitim Fakültesi, Temel Eğitim Bölümü, necla.tuzcuoglu@marmara.edu.tr, ORCID: https://orcid.org/00000002-2864-2422

${ }^{2}$ Marmara Üniversitesi, Atatürk Eğitim Fakültesi, Temel Eğitim Bölümü, ozge.cengiz@marmara.edu.tr, ORCID: https://orcid.org/0000-00030628-3825

${ }_{3}^{3}$ Marmara Üniversitesi, Atatürk Eğitim Fakültesi, Temel Eğitim Bölümü, gulsen.ilci@marmara.edu.tr, ORCID: https://orcid.org/0000-0003$2885-1176$
} 


\section{SUMMARY}

\section{Introduction}

Aggression is defined as behavior to harm someone and it is a negative reaction, especially in the face of prevention. According to Gültekin (2006), children who are aggressive have tendencies to crime. In these children, the ability to control themselves is very weak, and they may be inclined to force their wishes and desires upon others. When the factors related to aggression are considered, the most important one of many variables is the relationship between parents and children (Marcus ve Kramer, 2001). In some studies, it has been stated that deprivation of maternal support and warmth and violent or aggressive parental attitudes increase children's aggression levels (Papalia et al., 2003). It has also been stated that in the preschool period, it is important to investigate the factors related to the concept of family, which have a great effect on children's negative behaviors, such as aggression, and efforts should be made to determine intervention methods for the solution of these problems with the strengthening of work in this area (Crnic, Gaze, ve Hoffman, 2005). The general purpose of this study is to determine the relationship between the aggressive tendencies of preschool-age children and the levels of interest of their mothers. In addition, the aggressive tendencies of preschool-age children and their mothers' levels of interest are examined in terms of gender, age of the child, number of siblings, birth order, maternal age, maternal education status, and maternal working status.

\section{Method}

The research was carried out with a relational screening model, which is one of the quantitative research methods. The study group comprised 218 children attending preschool education institutions in Istanbul in the 2018-2019 academic year and their mothers. In this research, the following data collection tools were used: "The Personal Development Form," developed by the researchers; "The Aggression Scale for Children Aged 36-72 Months," developed by Kaynak, Kan, and Kurtulmuş (2016); and the "Development of Parental Involvement Towards Children Scale" developed by Sucuoğlu, Özkal, Demirtaş, and Güzeller (2015).

\section{Results}

The levels of aggression of the preschool children were below average; the mothers' levels of interest were above average. Boys' aggressive tendencies were higher than those of girls. The interest levels of mothers did not differ according to the gender of the child. The levels of aggressive tendencies of children and of mothers' interest did not differ according to the children's ages, their siblings, birth order, or maternal age. Furthermore, the levels of aggressive tendencies of children did not differ according to the educational status of their mothers. Mothers who were university graduates were more interested in their children than mothers with primary or secondary school education. Children of working mothers were more aggressive than those with housewives for mothers. The mothers' levels of interest in their children did not differ according to the working status of the mothers. A significant and negative correlation was found between the aggressive tendencies of the children and their mothers' interest levels. 


\section{Discussion and Conclusion}

According to the results of this study, the boys had higher tendencies to aggression than the girls. In Turkey, there is a widespread cultural belief that men have dominant characters and are able to use the power of force; however, women should be more harmonious and calm individuals. It can be thought that children have been educated in this direction by their families from an early age. The children's aggression tendency levels did not differ according to their ages. When related studies are examined, it is seen that the aggression levels of children do not differ according to their ages and young children do not have more aggressive behaviors compared to older children. Therefore, it can be said that more research is needed on the related variables. The levels of aggressive tendencies of children did not differ according to their numbers of siblings. Similarly, in the studies by İkiz and Öztürk-Samur (2016) and Ay (2017), physical and relational aggression levels of children did not differ according to the number of siblings. Levels of aggressive tendencies of the children did not differ according to birth order, and in the studies of İkiz and ÖztürkSamur (2016), Ay (2017), and Şen (2009), similarly, the physical and relational aggression levels of children did not differ according to their birth order. Interest levels of mothers did not differ according to maternal age. The reason for this may be that the interest of mothers is instinctive and that there is a positive attitude towards motherhood at any age. The level of aggressive tendencies of children did not differ according to the educational status of their mothers. Uysal and Dinçer (2013) and Ay (2017) also stated in their studies that the level of aggression of children did not change according to the educational level of the mother. In this study, mothers' relations within close circles may have had a decreasing effect on the differences between their educational backgrounds. The children of working mothers were more aggressive than children with housewives for mothers in this study. However, in the study by Kadan (2010), it was stated that children whose mothers were not working were more aggressive than those whose mothers were working. The interest levels of the mothers did not differ according to the working status of the mother. Although it is thought that working mothers may be less interested in their children, it is likely that they could close this gap by spending quality time with their children. According to the results of this study, the aggression of children decreases with increasing maternal interest. Maternal interest can be effective in the development of many positive attitudes and behaviors in children and can contribute to the development of communication and social skills. It was concluded that the interest of mothers was effective in reducing violent behavior (Flouri, 2006; Anderson ve Minke, 2007). Therefore, it can be said that the tendency towards aggression decreases as the interest of the mother increases. 


\section{GİRIŞ}

Saldırganlık, davranış bilimlerindeki diğer kavramlara benzer olarak çok boyutlu bir anlam taşımaktadır. Bu nedenle nörolojide, psikiyatride, psikolojide, psikolojinin farklı alt dallarında saldırganlığın tanımı değişmektedir (Köknel, 1996). Çeşitli alan uzmanları saldırganlığın tanımı konusunda farklı görüşlere sahip olsalar da ortak kabul edilen bazı tanımlamalar da mevcuttur. Genellikle tanımlarda bir bireyin zararsız veya masum başka bir bireye zarar verme ya da acı çektirme niyeti taşıması, bu niyetini de davranışlarına yansıtması üzerinde durulmaktadır (Ersan, 2017). Bu çalışmada okul öncesi dönem çocuklarının sergiledikleri saldırgan davranışlar üzerinde durulduğu için davranışçı veya sosyal öğrenme yaklaşımlarında saldırganlığa yönelik olarak benimsenen bakış açısı temel alınmıştır. Söz konusu yaklaşımlarda saldırganlık kavramı, başkalarını inciten her türlü amaçlı davranışlar ve eylemler olarak tanımlanmaktadır (Freedman, Sears ve Carlsmith, 1998; Kaymak-Özmen, 2004). Araştırmanın sosyal bilimler alanında yürütülen bir çalışma olması ve kullanılan ölçme aracının da engellenme-saldırganlık kuramına dayanması nedeniyle engellenme-saldırganlık kuramı temel alınmıştır. Bu kuramda daha çok toplumsal koşullar dikkate alınmaktadır (Dever ve Bulut, 2017). John Dollard tarafından geliştirilen engellenmesaldırganlık kuramında saldırganlık, hedefe ulaşırken karşılaşılan engellere cevap verme biçimi olarak tanımlanmıştır (Fromm, 1993; McAllister ve Schmid, 2011).

Toplumsal koşulların dikkate alındığı bir diğer kuram olan sosyal öğrenme kuramına göre insan toplumsallaşmanın sonucunda saldırganlığı öğrenmektedir (Eroğlu, 2009). Saldırganlığın öğrenme boyutunun olması özellikle çocuklar açısından büyük önem taşımaktadır. Okul öncesi dönemde çocuklar model alarak ve taklit ederek birçok davranışı öğrendikleri için yetiştikleri ortamın da davranış geliştirmelerinde önemli olduğu söylenebilir. İnan, Karagözoğlu ve Şimşek'e (2014) göre; çocuklar içinde bulundukları ortamlarda isteyerek veya istemeyerek birçok davranışta bulunurlar. Herhangi bir canlıya bir nesneyi yönelterek zarar verebilirler. Bir nesneyi itme, kırma, çekme, fırlatma gibi davranışlarda bulunabilirler. Bir canlıya yönelik olarak fiziksel, sözlü veya dolaylı bir şekilde rahatsızlık verici davranışlar sergileyebilirler. Çocuğun bu tür davranışları etrafındaki nesnelere zarar vermesiyle veya çevresindeki insanları rahatsız etmeye başlamasıyla sonuçlandığında bu durum, saldırganlığın düşünülmesine yol açmaktadır.

Çocukların gösterdikleri saldırganlık türleri Miller (2002) tarafindan dört alt gruba ayrılmıştır:

- Sözlü olarak gerçekleştirilen saldırganlık: Tehdit etme, kızma, bağırma, aşağılama, şiddet uygulama vb. 
- Nesnelere yönelik gerçekleştirilen saldırganlık: Nesneleri yakma, fırlatma, kapı çarpma, nesnelere vurma vb.

- Bireyin kendine yönelik gerçekleştirilen fiziksel saldırganlık: İntihar etmeye çalışma, duvara başını vurma, vücuda zarar verme, kanatma vb.

- Başkalarına yönelik gerçekleştirilen saldırganlık: İtme, fiziksel olarak saldırı, tekme atma, yumruk atma, tehdit etme vb.

Okul öncesi dönemde duygusal ve sosyal yönden yeterli destek alamayan çocuklar, okula başladıklarında arkadaşlarına yönelik olarak alay etme, saldırganlık, zorbalık gibi problemli davranışlar sergileyebilmektedir (Özbey ve Alisinanoğlu, 2009). Bay-Hinitz (2001) saldırgan davranışların ortaya çıkma nedenlerini bilgi ve beceri eksikliğinin yanı sıra duygusal yönden yaşanan sorunların davranışlara yansıtılması olarak açıklamışır. Ayrıca saldırgan davranışların öğrenilmesinde medyanın, çocuğun yakın çevresinin, arkadaş ortamının ve özellikle yetişkinlerin etkisinin olduğunu da belirtmiştir.

Saldırgan davranışların temelinde çocuğa sergilenen ebeveyn tutumlarının büyük etkisi vardır (Alisinanoğlu ve Kesicioğlu, 2010). Erbaş, Kurcali-İftar ve Tekin-İftar'a (2004) göre, aşırı disiplinli, baskıcı, aşağılayıcı veya aşırı koruyucu ebeveyn tutumları, aile içi olumsuz yaşantılar, genetik faktörler gibi etmenlerin de sorunlu davranışlar üzerinde etkilerinin olabileceği düşünülmektedir Yıldız'a (2004) göre çocuklarda saldırganlık davranışlarının görülmesinin nedenleri arasında kültürel ve ekonomik açıdan elverişsiz bir çevrede bulunma, olumsuz öğrenmelerin gerçekleştiği ve yetersiz etkileşim ve iletişimin hakim olduğu bir aile ortamına sahip olma gibi durumlar göz önünde bulundurulmalidir.

Saldırganlıkla ilgili faktörler ele alındığında, birçok değişken arasında en önemlisi anne-baba-çocuk ilişkisidir. Marcus ve Kramer'e (2001) göre aile bireyleri arasında etkili iletişim gerçekleşmesi halinde kurulan yakın ilişkiler, çocukların daha düşük düzeyde saldırgan davranışlarda bulunmalarına katkı sağlamakla birlikte akranlarıyla da güçlü sosyal ilişkiler kurmalarını desteklemektedir. Aile ortamı çocuklara isteklerin özgür bir biçimde dile getirilebildiği, aile bireyleri ile sıcak ilişkilerin kurulabildiği, problemlerin rahatlıkla çözülebildiği, gerekli durumlarda kabullenmenin öğrenilebildiği sağlıklı, nitelikli ve kaliteli bir sosyal ortam sunmalıdır. Bunun sağlanması için de anne ve babaların çocuklarının ilgi ve ihtiyaçlarını karşılayabilmesi, çocuk gelişimi ile ilgili gerekli olan temel bilgileri edinmiş olmaları gerekmektedir. Böylelikle saldırgan davranışlara yol açan etmenler mümkün olduğunca önlenmiş olacaktır (Çiftci-Topaloğlu, 2013). 
Yapılan bazı çalışmalarda özellikle anne desteği ve sıcaklığından mahrum kalmanın, şiddet unsurları içeren ve saldırgan tutumdaki anne-baba davranışlarının çocukların saldırganlık düzeylerini artırdıkları belirtilmiştir (Akt. Papalia, vd., 2003). Saldırgan davranışlarda bulunan çocuklar, bu davranışlarını aslında annelerine yönelik olarak sergilemekte, annelerine olan ihtiyaçlarını bu şekilde belli etmeye çalışmaktadır. Antisosyal davranışlar gösteren çocuklar bu durumlarını iyileştirme ihtiyacı duyarlar. Nitekim saldırganlıkları bir yardım arayışı ve çağrısıdır. Çocuklar temel ihtiyaçlarının karşılanmasını isterler fakat; anneler bu ihtiyaçların bir kısmını karşılayabilirler. Her durumda bir eksiklik durumu yaşanacaktır. Anneler yalnızca çocukların sıklıkla tekrarladıkları ihtiyaç durumlarını giderebilir zira oluşan eksiklik çocuklarda saldırganlık duygularını harekete geçirebilir (Winnicott, 1956).

Çocukların ilerleyen dönemler açısından riskli olarak değerlendirilebilecek davranışlarının önüne geçilmesine veya meydana gelen davranışların ortadan kaldırılmasına yönelik gerçekleştirilen müdahale çalışmaları, rahatsız edici ya da zarar verici davranışlanın oluşmasının engellenmesinde ya da çocukların iyi davranışa doğru yönlendirilmesinde oldukça önemli rol oynamaktadır. Bu nedenle okul öncesi dönemde çocukların saldırganlık gibi olumsuz davranışlarda bulunmalarında büyük etkisi olan aile kavramı ile ilgili faktörlerin araştırılması, bu sorunların çözümüne ilişkin müdahale yöntemlerinin belirlenmeye çalışılması ve söz konusu alanda çalışılmaya devam edilmesi gerektiği belirtilmektedir (Alisinanoğlu ve Kesicioğlu, 2010; Crnic, Gaze ve Hoffman, 2005; İkiz ve Öztürk Samur, 2016; Özbey, 2010; Uysal ve Dinçer, 2013; Yizhen, Junxia, Yan ve Jun, 2006).

Okul öncesi dönemdeki çocukların saldırganlık düzeylerine ilişkin ülkemizde yapılan çalışmalarda genellikle; ebeveyn tutumları (İkiz ve Öztürk-Samur, 2016; Kutlu, 2014), öğretmenlerin baş etme stratejileri (Öngören-Özdemir ve Tepeli, 2016), duygu ifade etme ve duygu düzenleme (Ersan, 2017), müdahale yöntemi olarak ebeveyn eğitim programının geliştirilmesi (Sayın, 2014) konularına ağırlık verilirken dünyada yapılan araştırmalarda; saldırganlığın dil gelişimi ile ilişkisi (Bonica, Arnold, Fisher, Zeljo ve Yershova, 2003), kişilik özellikleri ve sosyal davranışlar (Chen, Wang, Chen ve Liu, 2002), sosyal problem çözme becerileri (Jarvinen, 2001), kontrol odağ1 (Osterman, vd., 1999) gibi konuların araştırıldığı tespit edilmiştir. İlgili literatür incelendiğinde okul öncesi dönem çocuklarının saldırganlık yönelim düzeyleri ile annelerinin ilgi düzeylerinin birlikte ele alındığı bir çalışmaya rastlanmamışır. Alan yazında çocukların saldırganlık düzeyleri daha çok aile bireyleri ile ilişkiler, aile içi iletişim, ebeveyn tutumları, anne-babanın öğrenim durumu, annenin çalışma durumu gibi değişkenlerle birlikte ele alınmıştır. Okul öncesi dönem çocukları küçük yaşta olmalarından dolayı özellikle anneleriyle daha çok zaman geçirmekte ve anne ilgisine daha çok ihtiyaç duymaktadırlar. Bu nedenle çocuklarda görülen saldırgan davranışlar ile anne ilgisinin ilişkili 
olabileceği ve bu davranış sorunlarının çözümünde anne desteğinin önemli olacağı düşünülebilir. Söz konusu konuya ilişkin olarak ülkemizde yapılmış bir çalışmaya rastlanmamıştır.

$\mathrm{Bu}$ araştırmanın genel amacı, okul öncesi dönem çocuklarının saldırganlık yönelimleri ile annelerinin ilgi düzeyleri arasındaki ilişkinin tespit edilmesidir. Bu genel amaç doğrultusunda aşağıdaki alt amaçlar belirlenmiştir.

- Okul öncesi dönem çocuklarının saldırganlık yönelimleri ile annelerin ilgi düzeyleri arasında anlamlı bir ilişki var mıdır?

- Okul öncesi dönem çocuklarının saldırganlık yönelimleri ve annelerin ilgi düzeyleri cinsiyet, çocuğun yaşı, kardeş sayısı, doğum sırası, annenin yaşı, annenin eğitim durumu, annenin çalışma durumu değişkenlerine göre anlamlı bir farklılık göstermekte midir?

\section{YÖNTEM}

\section{Araştırma Modeli}

Bu araştırmada, okul öncesi dönem çocuklarının saldırganlık yönelimleri ile anne ilgileri arasındaki ilişki incelendiğinden; araştırma, nicel araştırma yöntemlerinden biri olan ilişkisel tarama modeli ile yürütülmüştür. İlişkisel tarama modelleri, iki veya daha çok sayıdaki değişken arasında birlikte değişim varlığını ve/veya derecesini belirlemeyi amaçlayan araştırma modelleridir (Karasar, 2013:81).

\section{Çalışma Grubu}

Araştırmanın çalışma grubunu 2018-2019 eğitim ve öğretim yılında İstanbul ili, Ataşehir, Çekmeköy, Sultanbeyli ve Kadıköy ilçelerinde Milli Eğitim Bakanlı̆̆ı'na bağlı okul öncesi eğitim kurumlarına devam etmekte olan 218 çocuk oluşturmaktadır. Çalışma grubundaki ilçeler uygun örnekleme yöntemi ile belirlenirken; ilçelerde bulunan okullar basit seçkisiz örnekleme yöntemi ile belirlenmiştir. 
Çalışma grubuna ait demografik bilgiler Tablo 1'de sunulmuştur.

Tablo 1. Çalışma grubuna ait demografik bilgiler

\begin{tabular}{|c|c|c|c|c|c|}
\hline Çocuğun Cinsiyeti & f & $\%$ & Anne Yaşı & $\mathrm{f}$ & $\%$ \\
\hline $\begin{array}{c}\text { Kiz } \\
\text { Erkek } \\
\text { Toplam }\end{array}$ & $\begin{array}{l}112 \\
106 \\
218\end{array}$ & $\begin{array}{l}51,4 \\
48,6 \\
100\end{array}$ & $\begin{array}{c}24-28 \\
29-33 \\
34-38 \\
39-43 \\
43 \text { ve üstü } \\
\text { Toplam } \\
\end{array}$ & \begin{tabular}{c|}
32 \\
40 \\
71 \\
44 \\
31 \\
218 \\
\end{tabular} & $\begin{array}{l}14,7 \\
18,3 \\
32,6 \\
20,2 \\
14,2 \\
100\end{array}$ \\
\hline Çocuğun Yaşı (Ay) & f & $\%$ & Anne Eğitim Düzeyi & f & $\%$ \\
\hline $\begin{array}{c}50-54 \\
55-59 \\
60-64 \\
65-69 \\
70 \text { ve üstü } \\
\text { Toplam }\end{array}$ & $\begin{array}{c}30 \\
30 \\
46 \\
71 \\
41 \\
218\end{array}$ & $\begin{array}{l}13,8 \\
13,8 \\
21,1 \\
32,5 \\
18,8 \\
100\end{array}$ & $\begin{array}{c}\text { İlkokul } \\
\text { Ortaokul } \\
\text { Lise } \\
\text { Universite } \\
\text { Lisans } \\
\text { Lisansüstü } \\
\text { Toplam }\end{array}$ & $\begin{array}{c}30 \\
35 \\
75 \\
45 \\
33 \\
218\end{array}$ & $\begin{array}{l}13,8 \\
16,1 \\
34,4 \\
20,6 \\
15,1 \\
100\end{array}$ \\
\hline Kardeş Sayısı & $\mathrm{f}$ & $\%$ & Anne Çalışma Durumu & f & $\%$ \\
\hline $\begin{array}{c}0 \\
1 \\
2 \\
3 \\
\text { Toplam } \\
\end{array}$ & \begin{tabular}{c|}
51 \\
94 \\
37 \\
36 \\
218 \\
\end{tabular} & $\begin{array}{l}23,4 \\
43,1 \\
17,0 \\
16,5 \\
100\end{array}$ & $\begin{array}{c}\text { Çalışan } \\
\text { Çalışmayan } \\
\text { Toplam }\end{array}$ & $\begin{array}{c}96 \\
122 \\
218\end{array}$ & $\begin{array}{c}44 \\
56 \\
100\end{array}$ \\
\hline Doğum S1ras1 & f & $\%$ & & & \\
\hline $\begin{array}{c}1 \\
2 \\
3 \\
\text { Toplam }\end{array}$ & $\begin{array}{c}93 \\
94 \\
31 \\
218\end{array}$ & $\begin{array}{l}42,7 \\
43,1 \\
14,2 \\
100\end{array}$ & & & \\
\hline
\end{tabular}

\section{Veri Toplama Araçları}

$\mathrm{Bu}$ araştırmada veri toplama aracı olarak; araştırmacılar tarafından oluşturulan "Kişisel Bilgi Formu”, “36-72 Aylık Çocuklara Yönelik Saldırganlık Yönelim Ölçeği” ve "Çocuğa Yönelik AnneBaba İlgisi Ölçeğì" kullanılmıştır.

\section{6-72 Aylık Çocuklara Yönelik Saldırganlık Yönelim Ölçeği}

“36-72 Aylık Çocuklara Yönelik Saldırganlık Yönelim Ölçeği” Engellenme-Saldırganlık Teorisi temel alınarak, 36-72 aylık çocukların saldırganlıklarını nelere ya da kimlere yönelttiklerini tespit etme amacıyla geliştirilmiştir. Yapılan faktör analizi neticesinde ölçek 27 madde ve 4 alt boyuttan oluşmaktadır. Bu alt boyutlar sırasıyla; başkalarına yönelik fiziksel saldırganlık, başkalarına yönelik ilişkisel saldırganlık, kendine yönelik saldırganlık ve eşyalara/nesnelere yönelik saldırganlık olarak ifade edilmiştir. Ölçeğin tamamı için Cronbach alpha iç tutarlılık katsayısı .95 olarak tespit edilirken; alt boyutlar için sırası ile .94, .94, .85 ve .92 olarak belirlenmiştir (Kaynak, Kan ve Kurtulmuş, 2016). 


\section{Çocuğa Yönelik Anne-Baba İlgisi Ölçĕ̆i}

“Çocuğa Yönelik Anne-Baba İlgisi Ölçeği” Sucuoğlu, Özkal, Demirtaş ve Güzeller (2015) tarafından okul öncesi eğitim kurumlarına devam eden 4-6 yaşındaki çocukların anne babalarının çocuklarına yönelik ilgi düzeylerini belirleme amacıyla geliştirilmiştir. Ölçek anne ve babalara iki ayrı form şeklinde hazırlanmıştır. Açımlayıcı faktör analizinde ölçeğin anne ilgi formunun 34 madde ve 4 faktör, baba ilgi formunun ise 40 madde ve 3 faktörden oluştuğu görülmüştür. Cronbach Alpha katsayıları anne ilgi formu için 0.91 ve baba ilgi formu için 0.94 olarak bulunmuştur (Sucuoğlu, Özkal, Demirtaş ve Güzeller, 2015). Bu araştırmada ölçeğin yalnızca anne formu kullanılmıştır.

\section{Verilerin Toplanmas1}

Uygulama öncesi İstanbul İl Milli Eğitim Müdürlüğü’nden alınan izin sonucunda araştırmanın yapıldığı ilçelerdeki okullara gidilerek kullanılan ölçeklerden ilki çocukları adına annelerin doldurması için annelere, ikinci ölçek yine çocuklar adına öğretmenlerin doldurması için öğretmenlere elden dağıtılmış ve doldurulduktan sonra teslim alınmıştır. Uygulama öncesi anneler ve öğretmenlere araştırmanın önemi ve eğitime olan katkısı açıklanmış, içtenlikle sorulara cevap verilmesinin araştırma sonuçları için önemli olacağı vurgulanarak cevapların objektifliği ve içtenliği konusunda gerekli yapılandırma bizzat araştırmacılar tarafından yapılmışır.

\section{Verilerin Analizi}

Araştırmada, öncelikle verilerin normal dağılıp dağılmadığına Kolmogorov-Smirnov testi ile bakılmış; verilerin normal dağıldığı görülmüştür ( $\mathrm{p}>.05$ ). Okul öncesi dönem çocuklarının saldırganlık yönelimleri ile anne-baba ilgisi puanları arasındaki ilişkiyi incelemek üzere Pearson momentler çarpımı korelasyon katsayısı analizi kullanılmıştır. Ayrıca saldırganlık yönelimleri ve anne-baba ilgisi ölçeği puanlarının cinsiyet ve anne çalışma durumu değişkenine göre farklılaşıp farklılaşmadığını belirlemek üzere bağımsız gruplar t-testi,; yaş, kardeş sayısı doğum sırası, anne yaş1 ve anne eğitim düzeyi değişkenlerine göre farklılaşıp farklılaşmadığını belirlemek üzere tek yönlü varyans analizi (ANOVA) uygulanmıştır. Veriler istatistiksel paket programda çözümlenmiş ve anlamlılık düzeyi .05 olarak değerlendirilmiştir.

\section{BULGULAR}

Bu bölümde okul öncesi dönem çocuklarının saldırganlık yönelimleri ile annelerinin ilgi düzeylerinin incelendiği araştırma sorularını açılayan istatistiksel analizlere yer verilmiştir. 
Tablo 2. Saldırganlık yönelimi ile anne ilgisi ölçek puanları arasındaki ilişkiye ait pearson çarpım momentler korelasyon katsayısı sonuçları

\begin{tabular}{lccccc}
\hline Değişkenler & $\mathbf{n}$ & $\overline{\mathbf{X}}$ & $\mathbf{s s}$ & $\mathbf{r}$ & $\mathbf{p}$ \\
\hline Saldırganlık Yönelimi & 218 & 37,22 & 10,24 & & \multirow{2}{*}{.21} \\
\cline { 1 - 4 } Anne İlgisi & 218 & 136,61 & 16,47 & & $.001^{* *}$ \\
\hline
\end{tabular}

$p^{* *}<.01$

Tablo 2'ye göre okul öncesi dönem çocuklarının saldırganlık yönelimleri ile anne ilgileri arasında düşük düzeyde ve negatif yönde anlamlı bir ilişki bulunmuştur ( $p<.01 ; \mathrm{r}=.21)$. Köse (2008)'e göre korelasyon katsayısının gücü; 0.00- 0.25 çok zayıf ilişki, 0.26- 0.49 zayıf ilişki, 0.50- 0.69 orta ilişki, 0.70- 0.89 yüksek ilișki, 0.90- 1.0 çok yüksek ilișki şeklinde verilen aralıklarla belirlenebilmektedir. Bu sonuca göre; çocukların saldırganlık yönelimleri anne ilgileri arttıkça azalmaktadır.

Tablo 3. Okul öncesi dönem çocuklarının saldırganlık yönelimleri ve anne ilgilerinin cinsiyet değişkenine göre farklılaşma durumuna ilişkin yapılan bağımsız gruplar t-testi sonuçları

\begin{tabular}{|c|c|c|c|c|c|c|c|}
\hline & \multirow{2}{*}{ Cinsiyet } & \multirow{2}{*}{$\mathbf{n}$} & \multirow{2}{*}{$\bar{X}$} & \multirow{2}{*}{ ss } & \multicolumn{3}{|c|}{ t Testi } \\
\hline & & & & & $\mathrm{t}$ & $\mathrm{Sd}$ & $\mathrm{p}$ \\
\hline \multirow{2}{*}{$\begin{array}{l}\text { Saldırganlık } \\
\text { Yönelimi }\end{array}$} & $\mathrm{K}_{1 z}$ & 112 & 34,3 & 12,1 & \multirow{2}{*}{$-2,64$} & \multirow{2}{*}{216} & \multirow{2}{*}{$.02^{*}$} \\
\hline & Erkek & 106 & 38,7 & 8,5 & & & \\
\hline \multirow{2}{*}{ Anne İlgisi } & $\mathrm{K}_{1 z}$ & 112 & 134,6 & 17,21 & \multirow{2}{*}{$-1,80$} & \multirow{2}{*}{216} & \multirow{2}{*}{.07} \\
\hline & Erkek & 106 & 138,6 & 15,46 & & & \\
\hline
\end{tabular}

${ }^{*} p<.05$

Tablo 3'e göre erkek çocukların saldırganlık yönelim puan ortalamalarının $\overline{\mathrm{X}}_{\text {erkek }}=38,7$; ss $=8,5$ olduğu; kız çocukların ise saldırganlık yönelim puan ortalamalarının $\overline{\mathrm{X}}_{\mathrm{k} \text { เz }}=34,3$; ss $=12,1$ olduğu görülmektedir. Okul öncesi dönem çocuklarının saldırganlık yönelimleri cinsiyet değişkenine göre anlamlı farklılık göstermektedir $(\mathrm{t}(-2,64)=218 ; \mathrm{p}<.05)$. Ortalamalara bakıldığında erkek çocukların kız çocuklarına göre saldırganlık yönelim puan ortalamaları daha yüksektir.

Tablo 3'te kız çocukların annelerinin ilgi puan ortalamalar1 $\bar{X}_{\mathrm{k} \text { zz }}=134,6$; ss $=17,21$ olarak; erkek çocukların annelerinin ilgi puan ortalamalanı $\overline{\mathrm{X}}_{\text {erkek }}=138,6$; ss=15,46 olarak görülmektedir. Okul öncesi dönem çocuklarının annelerinin ilgi düzeyleri ile cinsiyet arasında anlamlı bir farklılık tespit edilmemiştir ( $\mathrm{p}>.05)$. 
Tablo 4. Okul öncesi dönem çocuklarının saldırganlık yönelimlerinin çocuk yaşı değişkenine göre farklılaşma durumuna ilişkin yapılan tek yönlü varyans analizi (Anova) sonuçları

\begin{tabular}{|c|c|c|c|c|c|c|c|c|c|c|}
\hline \multicolumn{5}{|c|}{$f, \overline{\mathrm{x}}$ ve $s s$ Değerleri } & \multicolumn{6}{|c|}{ ANOVA Sonuçları } \\
\hline Puan & Grup & $\mathrm{n}$ & $\overline{\mathrm{X}}$ & SS & Var. K. & $K T$ & $S d$ & $K O$ & $F$ & $p$ \\
\hline & $50-54$ & 30 & 35,60 & 10,94 & G.Aras1 & 405,29 & 4 & 101,32 & & \\
\hline & $55-59$ & 30 & 39,80 & 10,86 & G.İçi & 22360,14 & 213 & 104,98 & & \\
\hline Saldırganlık & $60-64$ & 46 & 35,97 & 10,25 & Toplam & 22765,43 & 217 & & ,96 & .42 \\
\hline \multirow[t]{3}{*}{ Yönelimi } & 65-79 & 71 & 36,97 & 8,02 & & & & & & \\
\hline & 70 ve üstü & 41 & 38,34 & 12,47 & & & & & & \\
\hline & Toplam & 218 & 37,22 & 10,24 & & & & & & \\
\hline
\end{tabular}

Tablo 4 incelendiğinde, 50-54 ay arasındaki çocukların saldırganlık yönelim puan ortalamalarının $\overline{\mathrm{X}}_{50-54}=35,60 ;$ ss=10,94 olduğu; 55-59 ay arasındaki çocukların saldırganlık yönelim puan ortalamalarının $\bar{X}_{55-59}=39,80$; ss=10,86 olduğu; 60-64 ay arasındaki çocukların saldırganlık yönelim puan ortalamalarının $\bar{X}_{60-64}=35,97$; ss=10,25 olduğu; 65-79 ay arasındaki çocukların saldırganlık yönelim puan ortalamalarının $\overline{\mathrm{X}}_{65-79}=36,97$; ss $=8,02$ olduğu; 70 ve üstü ay arasındaki çocukların saldırganlık yönelim puan ortalamalarının $\bar{X}_{75 \text { ve üstü }}=38,34$; ss=12,47 olduğu görülmektedir.

Okul öncesi dönem çocuklarının saldırganlık yönelimi puan ortalamaları ( $F=, 965$ p >.05) yaş değişkenine göre anlamlı bir farklılık göstermemektedir.

Tablo 5. Okul öncesi dönem çocuklarının anne ilgilerinin çocuk yaşı değişkenine göre farklılaşma durumuna ilişkin yapılan tek yönlü varyans analizi (Anova) sonuçları

\begin{tabular}{cccccccccccc}
\hline & $f, \overline{\mathrm{x}}$ ve & ss & Değerleri & \multicolumn{8}{c}{ ANOVA Sonuçlar1 } \\
\hline Puan & Grup & $\mathrm{n}$ & $\overline{\mathrm{x}}$ & ss & Var. K. & $K T$ & $S d$ & $K O$ & $F$ & $p$ \\
\hline \multirow{5}{*}{ Anne İlgisi } & $50-54$ & 30 & 134,06 & 18,33 & G.Arasi & 1624,92 & 4 & 406,23 & & \\
& $55-59$ & 30 & 131,63 & 18,73 & G.İçi & 57270,47 & 213 & 268,87 & & \\
& $60-64$ & 46 & 138,15 & 15,14 & Toplam & 58895,39 & 217 & & 1,51 & .20 \\
& $65-79$ & 71 & 136,64 & 16,69 & & & & & & \\
& 70 ve üstü & 41 & 140,36 & 13,69 & & & & & & \\
& Toplam & 218 & 136,61 & 16,47 & & & & & & \\
\hline
\end{tabular}

Tablo 5 incelendiğinde, 50-54 ay arasındaki çocukların annelerinin ilgi puan ortalamalarının $\overline{\mathrm{X}}_{50-54}$ =134,06; ss=18,33 olduğu; 55-59 ay arasındaki çocukların annelerinin ilgi puan ortalamalarının $\overline{\mathrm{X}}$ 55-59 $=131,63$; ss=18,73 olduğu; 60-64 ay arasındaki çocukların annelerinin ilgi puan ortalamalarının $\overline{\mathrm{X}}_{60-64}=138,15 ;$ ss=15,14 olduğu; 65-79 ay arasındaki çocukların annelerinin ilgi puan ortalamalarının $\bar{X}_{65-79}=136,64 ;$ ss $=16,69$ olduğu; 70 ve üstü ay arasındaki çocukların annelerinin ilgi puan ortalamalarının $\bar{X}_{75 \text { ve üstü }}=140,36$; ss=13,69 olduğu görülmektedir. Okul öncesi dönem 
çocuklarının anne ilgilerinin puan ortalamaları $(F=1,511$ p>.05) yaş değisskenine göre anlamlı bir farkl111k göstermemektedir.

Tablo 6. Okul öncesi dönem çocuklarının saldırganlık yönelimlerinin kardeş sayısı değişkenine göre farklılaşma durumuna ilişkin yapılan tek yönlü varyans analizi (Anova) sonuçları

\begin{tabular}{|c|c|c|c|c|c|c|c|c|c|c|}
\hline \multicolumn{5}{|c|}{$f, \overline{\mathrm{X}}$ ve $s s$ Değerleri } & \multicolumn{6}{|c|}{ ANOVA Sonuçları } \\
\hline Puan & Grup & $\mathrm{n}$ & $\overline{\mathrm{X}}$ & $s S$ & Var. K. & $K T$ & $S d$ & $K O$ & $F$ & $p$ \\
\hline \multirow{5}{*}{$\begin{array}{l}\text { Saldırganlık } \\
\text { Yönelimi }\end{array}$} & 0 & 51 & 37,09 & 9,57 & G.Aras1 & 143,54 & 3 & 47,84 & & \\
\hline & 1 & 94 & 37,69 & 10,30 & G.İçi & 22621,88 & 214 & 105,71 & & \\
\hline & 2 & 37 & 37,86 & 11,56 & Toplam & 22765,43 & 217 & & ,45 & .71 \\
\hline & 3 & 36 & 35,50 & 9,79 & & & & & & \\
\hline & Toplam & 218 & 37,22 & 10,24 & & & & & & \\
\hline
\end{tabular}

Tablo 6'ya bakıldığında kardeşi olmayan çocukların saldırganlık yönelim puan ortalamalarının $\overline{\mathrm{X}}_{0}$ $=37,09 ;$ ss=9,57 olduğu; 1 kardeşi olan çocukların saldırganlık yönelim puan ortalamalarının $\bar{X}_{1}$ $=37,69 ;$ ss $=10,30$ olduğu; 2 kardeşi olan çocukların saldırganlık yönelim puan ortalamalarının $\bar{X}_{2}$ $=37,86 ;$ ss=11,56 olduğu; 3 kardeşi olan çocukların saldırganlık yönelim puan ortalamalarının $\bar{X}_{3}$ $=35,50 ;$ ss=9,79 olduğu görülmektedir. Okul öncesi dönem çocuklarının saldırganlık yönelimi puan ortalamalarının ( $\mathrm{F}=, 453$ p>.05) kardeş sayısı değişkenine göre anlamlı bir farklılık göstermediği bulunmuştur.

Tablo 7. Okul öncesi dönem çocuklarının anne ilgilerinin kardeş sayısı değişkenine göre farklılaşma durumuna ilişkin yapılan tek yönlü varyans analizi (Anova) sonuçları

\begin{tabular}{|c|c|c|c|c|c|c|c|c|c|c|}
\hline \multicolumn{5}{|c|}{$f, \overline{\mathrm{x}}$ ve $s s$ Değerleri } & \multicolumn{6}{|c|}{ ANOVA Sonuçları } \\
\hline Puan & Grup & $\mathrm{n}$ & $\overline{\mathrm{X}}$ & SS & Var. K. & $K T$ & $S d$ & $K O$ & $F$ & $p$ \\
\hline \multirow{5}{*}{ Anne İlgisi } & 0 & 51 & 135,41 & 16,80 & G.Aras1 & 753,26 & 3 & 251,08 & & \\
\hline & 1 & 94 & 138,73 & 15,57 & G.İçi & 58142,13 & 214 & 271,69 & & \\
\hline & 2 & 37 & 134,64 & 19,70 & Toplam & 58895,39 & 217 & & 92 & .43 \\
\hline & 3 & 36 & 134,83 & 14,64 & & & & & & \\
\hline & Toplam & 218 & 136,61 & 16,47 & & & & & & \\
\hline
\end{tabular}

Tablo 7 incelendiğinde kardeşi olmayan çocukların annelerinin ilgi puan ortalamaları $\overline{\mathrm{X}}_{0}=135,41$; ss=16,80 olarak; 1 kardeşi olan çocukların annelerinin ilgi puan ortalamalarının $\bar{X}_{1}=138,73$; ss=15,57 olarak; 2 kardeşi olan çocukların annelerinin ilgi puan ortalamalarının $\overline{\mathrm{X}}_{2}=134,64$; ss=19,70 olarak; 3 kardeşi olan çocukların annelerinin ilgi puan ortalamalarının $\bar{X}_{3}=134,83$; ss=14,64 olarak görülmektedir. Okul öncesi dönem çocuklarının anne ilgisi puan ortalamalarının $(\mathrm{F}=, 924$ p>.05) kardeş sayısı değişkenine göre anlamlı bir farklılık göstermediği bulunmuştur. 
Tablo 8. Okul öncesi dönem çocuklarının saldırganlık yönelimlerinin doğum sırası değişkenine göre farklılaşma durumuna ilişkin yapılan tek yönlü varyans analizi (Anova) sonuçları

\begin{tabular}{|c|c|c|c|c|c|c|c|c|c|c|}
\hline \multicolumn{5}{|c|}{$f, \overline{\mathrm{X}}$ ve $s s$ Değerleri } & \multicolumn{6}{|c|}{ ANOVA Sonuçları } \\
\hline Puan & Grup & $\mathrm{n}$ & $\overline{\mathrm{X}}$ & $S S$ & Var. K. & $K T$ & $S d$ & $K O$ & $F$ & $p$ \\
\hline & 1 & 93 & 38,36 & 10,73 & G.Aras1 & 364,18 & 2 & 182,09 & & \\
\hline Saldırganlık & 2 & 94 & 37,00 & 9,94 & G.İçi & 22401,24 & 215 & 104,19 & & \\
\hline \multirow[t]{2}{*}{ Yönelimi } & 3 & 31 & 34,45 & 9,31 & Toplam & 22765,43 & 217 & & 1,74 & .17 \\
\hline & Toplam & 218 & 37,22 & 10,24 & & & & & & \\
\hline
\end{tabular}

Tablo 8'e bakıldığında ilk sırada doğan çocukların saldırganlık yönelim puan ortalamalarının $\bar{X}$ ilk $=38,36 ;$ ss $=10,73$ olduğu; ikinci sırada doğan çocukların saldırganlık yönelim puan ortalamalarının $\overline{\mathrm{X}}_{\text {ikinci }}=37,00 ;$ ss=9,94 olduğu; üçüncü sırada doğan çocukların saldırganlık yönelim puan ortalamalarının $\bar{X}_{\text {üçüncü }}=34,45$; ss=9,31 olduğu görülmektedir. Okul öncesi dönem çocuklarının saldırganlık yönelimi puan ortalamalarının ( $F=1,748$ p>.05) doğum sırası değişkenine göre anlamlı bir farklılık göstermediği belirlenmiştir.

Tablo 9. Okul öncesi dönem çocuklarının anne ilgilerinin doğum sırası değişkenine göre farklılaşma durumuna ilişkin yapılan tek yönlü varyans analizi (Anova) sonuçları

\begin{tabular}{ccccccccccc}
\hline & $f, \overline{\mathrm{x}}$ ve & $s s$ & Değerleri & \multicolumn{7}{c}{ ANOVA Sonuçlar1 } \\
\hline Puan & Grup & $\mathrm{n}$ & $\overline{\mathrm{x}}$ & ss & Var. K. & \multicolumn{1}{c}{$K T$} & $S d$ & $K O$ & $F$ & $p$ \\
\hline \multirow{3}{*}{ Anne İlgisi } & 1 & 93 & 138,58 & 15,69 & G.Aras1 & 1010,76 & 2 & 505,38 & & \\
& 2 & 94 & 136,17 & 17,61 & G.İçi & 578884,63 & 215 & 269,23 & & \\
& 3 & 31 & 132,09 & 14,56 & Toplam & 58895,39 & 217 & & 1,87 & .15 \\
& Toplam & 218 & 136,61 & 16,47 & & & & & & \\
\hline
\end{tabular}

Tablo 9'a bakıldığında ilk sırada doğan çocukların annelerinin ilgi puan ortalamaları $\bar{X}_{\text {ilk }}=138,58$; ss=15,69 olarak; ikinci sırada doğan çocukların annelerinin ilgi puan ortalamaları $\overline{\mathrm{X}}_{\text {ikinci }}=136,17$; ss=17,61 olarak; üçüncü sırada doğan çocukların annelerinin ilgi puan ortalamalar1 $\bar{X}_{\text {üçücü }}=132,09$; ss=14,56 olarak görülmektedir. Okul öncesi dönem çocuklarının anne ilgisi puan ortalamalarının $(\mathrm{F}=1,877 \mathrm{p}>0.05)$ doğum sırası değişkenine göre anlamlı bir farklılık göstermediği görülmektedir. 
Tablo 10. Okul öncesi dönem çocuklarının saldırganlık yönelimlerinin anne yaşı değişkenine göre farklılaşma durumuna ilişkin yapılan tek yönlü varyans analizi (Anova) sonuçları

\begin{tabular}{|c|c|c|c|c|c|c|c|c|c|c|}
\hline \multicolumn{5}{|c|}{$f, \overline{\mathrm{x}}$ ve $s s$ Değerleri } & \multicolumn{6}{|c|}{ ANOVA Sonuçları } \\
\hline Puan & Grup & $\mathrm{n}$ & $\overline{\mathrm{x}}$ & ss & Var. K. & $K T$ & $S d$ & $K O$ & $F$ & $p$ \\
\hline & $24-28$ & 32 & 39,18 & 10,89 & G.Aras1 & 557,39 & 4 & 106,73 & & \\
\hline & $29-33$ & 40 & 38,32 & 10,45 & G.İçi & 22208,03 & 213 & 104,87 & & \\
\hline Saldırganlık & $34-38$ & 71 & 37,53 & 10,45 & Toplam & 22765,43 & 217 & & 1,01 & .39 \\
\hline \multirow[t]{3}{*}{ Yönelimi } & $39-43$ & 44 & 37,02 & 7,77 & & & & & & \\
\hline & 43 ve üstü & 31 & 36,16 & 11,77 & & & & & & \\
\hline & Toplam & 218 & 37,22 & 10,24 & & & & & & \\
\hline
\end{tabular}

Tablo 10 incelendiğinde 24-28 yaş aralığındaki annelerin çocuklarının saldırganlık yönelim puan ortalamaları $\overline{\mathrm{X}}_{24-28}=39,18 ;$ ss $=10,89$ olarak; 29-33 yaş aralı̆̆ındaki annelerin çocuklarının saldırganlık yönelim puan ortalamaları $\overline{\mathrm{X}}_{29-33}=38,32$; ss $=10,45$ olarak; $34-38$ yaş aralığındaki annelerin çocuklarının saldırganlık yönelim puan ortalamaları $\bar{X}_{34-38}=37,53$; ss $=10,45$ olarak; 3943 yaş aralı̆̆ındaki annelerin çocuklarının saldırganlık yönelim puan ortalamaları $\overline{\mathrm{X}}_{39-43}=37,02$; ss $=7,77$ olarak; 43 ve üzeri yaş aralığındaki annelerin çocuklanının saldırganlık yönelim puan ortalamaları $\overline{\mathrm{X}}_{43 \text { veüzeri }}=36,16$; ss=11,77 olarak görülmektedir. Okul öncesi dönem çocuklarının saldırganlık yönelimi puan ortalamalarının ( $\mathrm{F}=1,018 \mathrm{p}>.05)$ anne yaşı değişkenine göre anlamlı bir farkl1lık göstermediği görülmektedir.

Tablo 11. Okul öncesi dönem çocuklarının annelerinin ilgi düzeylerinin anne yaşı değişkenine göre farklılaşma durumuna ilişkin yapılan tek yönlü varyans analizi (Anova) sonuçları

\begin{tabular}{|c|c|c|c|c|c|c|c|c|c|c|}
\hline \multicolumn{5}{|c|}{$f$, $\overline{\mathrm{x}}$ ve $s s$ Değerleri } & \multicolumn{6}{|c|}{ ANOVA Sonuçları } \\
\hline Puan & Grup & $\mathrm{n}$ & $\overline{\mathrm{X}}$ & ss & Var. K. & $K T$ & $S d$ & $K O$ & $F$ & $p$ \\
\hline \multirow{6}{*}{ Anne İlgisi } & $24-28$ & 32 & 137,00 & 18,97 & G.Aras1 & 916,95 & 4 & 229,23 & & \\
\hline & $29-33$ & 40 & 132,42 & 21,40 & G.İçi & 57978,44 & 213 & 272,19 & & \\
\hline & $34-38$ & 71 & 137,57 & 14,83 & Toplam & 58895,39 & 217 & & 84 & .50 \\
\hline & $39-43$ & 44 & 138,40 & 14,46 & & & & & & \\
\hline & 43 ve üstü & 31 & 136,90 & 12,33 & & & & & & \\
\hline & Toplam & 218 & 136,61 & 16,47 & & & & & & \\
\hline
\end{tabular}

Tablo 11 incelendiğinde 24-28 yaş aralığındaki annelerin ilgi puan ortalamaları $\overline{\mathrm{X}}_{24-28}=137,00$; ss=18,97 olarak; 29-33 yaş aralı̆ğndaki annelerin ilgi puan ortalamaları $\bar{X}_{29-33}=132,42$; ss $=21,40$ olarak; 34-38 yaş aralığındaki annelerin ilgi puan ortalamaları $\bar{X}_{34-38}=137,57$; ss=14,83 olarak; 3943 yaş aralığındaki annelerin ilgi puan ortalamaları $\bar{X}_{39-43}=138,40$; ss=14,46 olarak; 43 ve üzeri yaş aralı̆̆ındaki annelerin ilgi puan ortalamaları $\overline{\mathrm{X}}_{43 \mathrm{veüzeri}}=136,90$; ss=12,33 olarak görülmektedir. Okul öncesi dönem çocuklarının anne ilgisi puan ortalamalarının $(F=, 842, p>.05)$ anne yaşı değişkenine göre anlamlı bir farkl1lık göstermediği görülmektedir. 
Tablo 12. Okul öncesi dönem çocuklarının saldırganlık yönelimlerinin annenin eğitim düzeyi değişkenine göre farklılaşma durumuna ilişkin yapılan tek yönlü varyans analizi (Anova) sonuçları

\begin{tabular}{|c|c|c|c|c|c|c|c|c|c|c|}
\hline \multicolumn{5}{|c|}{$f, \overline{\mathrm{x}}$ ve $s s$ Değerleri } & \multicolumn{6}{|c|}{ ANOVA Sonuçları } \\
\hline Puan & Grup & $\mathrm{n}$ & $\overline{\mathrm{X}}$ & SS & Var. K. & $K T$ & $S d$ & $K O$ & $F$ & $p$ \\
\hline \multirow{6}{*}{$\begin{array}{l}\text { Saldırganlık } \\
\text { Yönelimi }\end{array}$} & İlkokul & 30 & 35,10 & 9,23 & G.Aras1 & 517,83 & 4 & 129,45 & & \\
\hline & Ortaokul & 35 & 37,82 & 8,60 & G.İçi & 22247,59 & 213 & 104,44 & & \\
\hline & Lise & 75 & 37,26 & 11,21 & Toplam & 22765,43 & 217 & & 1,23 & .29 \\
\hline & Üniversite & 45 & 39,53 & 10,40 & & & & & & \\
\hline & Lisansüstü & 33 & 35,24 & 9,97 & & & & & & \\
\hline & Toplam & 218 & 37,22 & 10,24 & & & & & & \\
\hline
\end{tabular}

Tablo 12'ye bakıldığında annesi ilkokul mezunu olan çocukların saldırganlık yönelim puan ortalamalarının $\overline{\mathrm{X}}_{\text {ilkokul }}=35,10 ;$ ss=9,23 olduğu; annesi ortaokul mezunu olan çocukların saldırganlık yönelim puan ortalamalarının $\overline{\mathrm{X}}_{\text {ortaokul }}=37,82$; ss=8,60 olduğu; annesi lise mezunu olan çocukların saldırganlık yönelim puan ortalamalarının $\bar{X}_{\text {lise }}=37,26$; ss=11,21 olduğu; annesi üniversite mezunu olan çocukların saldırganlık yönelim puan ortalamalarının $\bar{X}_{\text {üniversite }}=39,53$; ss=10,40 olduğu; annesi lisansüstü mezunu olan çocukların saldırganlık yönelim puan ortalamalarının $\bar{X}_{\text {lisansüstü }}=35,24$; ss=9,97 olduğu görülmektedir. Okul öncesi dönem çocuklarının saldırganlık yönelimi puan ortalamalarının $(F=1,239$ p $>0,05)$ anne eğitim düzeyi değişkenine göre farklılık göstermediği görülmektedir.

Tablo 13. Okul öncesi dönem çocuklarının anne ilgilerinin annenin eğitim düzeyi değişkenine göre farklılaşma durumuna ilişkin yapılan tek yönlü varyans analizi (Anova) sonuçları

\begin{tabular}{|c|c|c|c|c|c|c|c|c|c|c|}
\hline \multicolumn{5}{|c|}{$f, \overline{\mathrm{X}}$ ve $s s$ Değerleri } & \multicolumn{6}{|c|}{ ANOVA Sonuçları } \\
\hline Puan & Grup & $\mathrm{n}$ & $\overline{\mathrm{X}}$ & SS & Var. K. & $K T$ & $S d$ & $K O$ & $F$ & $p$ \\
\hline \multirow{6}{*}{ Anne İlgisi } & $\overline{\text { İlkokul }}$ & 30 & 128,60 & 18,10 & G.Aras1 & 5492,09 & 4 & 1373,02 & & \\
\hline & Ortaokul & 35 & 129,74 & 17,55 & G.İçi & 53403,30 & 213 & 250,72 & & \\
\hline & Lise & 75 & 138,93 & 16,12 & Toplam & 58895,39 & 217 & & 5,47 & $.001 * *$ \\
\hline & Üniversite & 45 & 142,22 & 12,16 & & & & & & \\
\hline & Lisansüstü & 33 & 138,30 & 15,48 & & & & & & \\
\hline & Toplam & 218 & 136,61 & 16,47 & & & & & & \\
\hline
\end{tabular}

$p^{* *}<.01$

Tablo 13 incelendiğinde ilkokul mezunu annelerin ilgi puan ortalamalarının $\bar{X}_{\text {ilkokul }}=128,60$; ss=18,10 olduğu; ortaokul mezunu annelerin ilgi puan ortalamalarının $\bar{X}_{\text {ortaokul }}=129,74$; ss=17,55 olduğu; lise mezunu annelerin ilgi puan ortalamalarının $\bar{X}_{\text {lise }}=138,93$; ss=16,12 olduğu; üniversite mezunu annelerin ilgi puan ortalamalarının $\bar{X}_{\text {üniversite }}=142,22$; ss=12,16 olduğu; lisansüstü mezunu annelerin ilgi puan ortalamalarının $\bar{X}_{\text {lisansüstü }}=138,30$; ss=15,48 olduğu görülmektedir. Okul öncesi dönem çocuklarının anne ilgisi puan ortalamalarının $(F=5,476 \mathrm{p}<.01)$ anne eğitim düzeyi değişkenine göre anlamlı farklılık gösterdiği görülmektedir. İlgi puanları için yapılan homojenlik 
testi sonucunda; varyansların homojen dağılmadığı belirlenmiş $(\mathrm{p}=.04<.05)$; bu nedenle farklılıkların yönünü bulmak amacıyla Tamhane Testi uygulanmış ve sonuçları Tablo 14'te sunulmuştur.

Tablo 14. Okul öncesi dönem çocuklarının anne ilgilerinin annenin eğitim durumu değişkenine göre farklılaşma durumu ile ilgili yapılan tamhane testi sonuçları

\begin{tabular}{|c|c|c|c|c|}
\hline & I (Düzey) & Ĕ̆itim Düzeyi (J) & Ortalama Farkı (I-J) & $\mathrm{p}$ \\
\hline \multirow{20}{*}{ Anne İlgisi } & \multirow{4}{*}{ İlkokul } & Ortaokul & $-1,14$ & 1,00 \\
\hline & & Lise & $-10,33$ & .08 \\
\hline & & Üniversite & $-13,62$ & $.00^{* *}$ \\
\hline & & Lisansüstü & $-9,70$ & .23 \\
\hline & \multirow{4}{*}{ Ortaokul } & İlkokul & 1,14 & 1,00 \\
\hline & & Lise & $-9,19$ & .10 \\
\hline & & Üniversite & $-12,47$ & $.00^{* *}$ \\
\hline & & Lisansüstü & $-8,56$ & .31 \\
\hline & \multirow{4}{*}{ Lise } & İlkokul & 10,33 & .08 \\
\hline & & Ortaokul & 9,19 & .10 \\
\hline & & Üniversite & $-3,28$ & .90 \\
\hline & & Lisansüstü &, 63 & 1,00 \\
\hline & \multirow{4}{*}{ Üniversite } & İlkokul & 13,62 & $.00^{* *}$ \\
\hline & & Ortaokul & 12,47 & $.00^{* *}$ \\
\hline & & Lise & 3,28 & .90 \\
\hline & & Lisansüstü & 3,91 & .92 \\
\hline & \multirow{4}{*}{ Lisansüstü } & İlkokul & 9,70 & .23 \\
\hline & & Ortaokul & 8,56 & .31 \\
\hline & & Lise &,- 63 & 1,00 \\
\hline & & Üniversite & $-3,91$ & .92 \\
\hline
\end{tabular}

$p^{* *}<.001$

Tablo 14'da görüldüğü üzere annelerin çocuklarına olan ilgilerinin puan ortalamalarında; üniversite mezunu olan anneler ile ilkokul mezunu anneler arasında, üniversite mezunu olan anneler lehine anlamlı farklılığa rastlanmıştır. Yine üniversite mezunu olan anneler ile ortaokul mezunu anneler arasında, üniversite mezunu olan anneler lehine anlamlı düzeyde farklılaşma bulunmaktadır. Diğer eğitim durumları arasında anlamlı farklılı̆̆a rastlanmamıștır.

Tablo 15. Okul öncesi dönem çocuklarının saldırganlık yönelimleri ve anne ilgilerinin annenin çalışma durumu değişkenine göre farklılaşma durumuna ilişkin yapılan bağımsız gruplar t-testi sonuçları

\begin{tabular}{|c|c|c|c|c|c|c|c|}
\hline & \multirow{2}{*}{ Çalışma Durumu } & \multirow{2}{*}{$\mathrm{n}$} & \multirow{2}{*}{$\bar{X}$} & \multirow{2}{*}{ ss } & \multicolumn{3}{|c|}{ t Testi } \\
\hline & & & & & $\mathrm{t}$ & $\mathrm{Sd}$ & $\mathrm{p}$ \\
\hline \multirow{2}{*}{$\begin{array}{l}\text { Saldırganlık } \\
\text { Yönelimi }\end{array}$} & Çalışan & 96 & 39,45 & 10,64 & \multirow{2}{*}{2,83} & \multirow{2}{*}{216} & \multirow{2}{*}{$.03^{*}$} \\
\hline & Çalışmayan & 122 & 34,23 & 7,85 & & & \\
\hline \multirow{2}{*}{ Anne İlgisi } & Çalışan & 96 & 138,4 & 15,3 & \multirow{2}{*}{1,51} & \multirow{2}{*}{216} & \multirow{2}{*}{.13} \\
\hline & Çalışmayan & 122 & 135,1 & 17,2 & & & \\
\hline
\end{tabular}

${ }^{*} p<.05$ 
Tablo 15'e bakıldığında çalışan annelerin çocuklarının saldırganlık yönelim puan ortalamalarının $\bar{X}$ çalşan $=39,45 ;$ ss=10,64 olduğu; çalışmayan annelerin çocuklarının saldırganlık yönelim puan ortalamalarının $\overline{\mathrm{X}}_{\text {calısmayan }}=34,23$; ss=7,85 olduğu görülmektedir. Çalışan annelerin ilgi puan ortalamaları $\bar{X}_{\text {çalşan }}=138,4 ;$ ss=15,3 ve çalışmayan annelerin ilgi puan ortalamaları ${ }_{\text {çalısmayan }}=135,1$; ss=17,2 olarak bulunmuştur. Okul öncesi dönem çocuklarının saldırganlık yönelimleri annenin çalışma durumu değişkenine göre anlamlı farkllılı göstermektedir $(\mathrm{t}(2,83)=218 ; \mathrm{p}<.05)$. Ortalamalara bakıldığında çalışan annelerin çocuklarının çalışmayan annelerin çocuklarına göre saldırganlı yönelimleri daha yüksektir $\left(\bar{X}_{\text {erkek }}=38,7 ; \mathrm{ss}=8,5 ; \overline{\mathrm{X}}_{\mathrm{kz} z}=34,3\right.$; ss=12,1). Annelerin çalışma durumuna göre ilgi düzeylerinde istatistiksel olarak anlamlı bir farklılık bulunmamıştır ( $>$ >.05).

\section{SONUÇ ve TARTIŞMA}

Okul öncesi dönem çocuklarının saldırganlık yönelimleri ile annelerinin ilgi düzeylerinin incelendiği araştırma sonuçlarına göre; okul öncesi dönem çocuklarının saldırganlık yönelimleri ile anne ilgileri arasında düşük düzeyde ve negatif yönde anlamlı bir ilişki bulunmuştur. Bu sonuca göre; çocukların saldırganlık yönelimleri anne ilgileri arttıkça azalmaktadır. Anne baba ilgisi; çocuğun sosyalleşmesinde, eğitimle ilgili konularda ve problemli durumların çözümünde önemli bir etkendir (Bridge, 2001). Yine anne baba ilgisinin şiddet içeren davranışları azaltmada etkili olduğu sonucuna araştırmalarda ulaşılmıştır (Flouri, 2006; Anderson ve Minke, 2007). Bu nedenle anne ilgisi arttıkça saldırganlık yönelimlerinin azaldığı söylenebilir.

Cinsiyet değişkenine göre saldırganlık yönelim düzeylerinde, erkek çocukların saldırganlık yönelimlerinin kız çocuklarına göre daha yüksek düzeyde olduğunu sonucuna ulaşılmıştır. İkiz ve Öztürk-Samur'un (2016) çalışmasında ilişkisel saldırganlık boyutunda cinsiyete göre fark bulunmazken fiziksel saldırganlıkta erkeklerin kızlara göre düzeyi daha yüksek bulunmuştur. Dursun (2010) erkek çocukların sözel ve fiziksel saldırgan davranışlar sergilediklerini belirtmiştir. İlgili literatür incelendiğinde Ay (2017); Kartal (2014); Özbey ve Alisinanoğlu, (2009) yaptıklar1 araştırmalarda erkeklerin kızlara göre daha saldırgan oldukları sonucunu elde etmişlerdir. Söz konusu sonuçlar, bu araştırma sonucu ile paralellik göstermektedir. Toplumsallaşma sürecinde cinsiyet rolleri için kadınlara "Özgeci, şefkatli, besleyici, bağımlı, destekleyici, duygusal, sanatsal ve edebi” dişil özellikler yüklenirken erkeklere "iktidar ve egemenlik arayan; ben-merkezci, bireyci, bağımsız, rekabetçi, mücadeleci ve pragmatik" eril özellikler yüklenmektedir (Savran ve Demiryontan, 2016: 172-173). Yine geleneksel toplumsal cinsiyet rollerini oluşturan kadın ve erkek 
Özellikleri belirtilirken; kadınlarda "Pasiflik, bağımlılık, şefkat, merhamet, empati, duygusallık, besleyicilik, duyarlılık, yardımseverlik" gibi özellikler sırlanmışken, erkeklerde "Aktiflik, bağımsızlık, akılcılık (rasyonellik), denetim altında bulundurma, üstünlük kurma, saldırganlık, hırs, bireycilik, rekabet gibi özellikler sıralanmıştır (Bacacı Varoğlu, 2001: 324). Thomas'a (2003) göre ise, geleneksel cinsiyet rolleri erkekleri öfkelendiklerinde saldırgan davranışlar sergilemeleri cesaretlendirmektedir. Bu nedenle erkek çocukların saldırganlık düzeyleri kız çocuklara göre daha yüksek düzeyde bulunmuş olabilir.

Okul öncesi dönem çocuklarının anne ilgileri cinsiyete göre farklılaşmamaktadır. Anne ilgisi; çocuğun ev ya da okul ortamındaki eğitimine yönelik annenin göstermiş olduğu davranış ve etkinlikleri içerdiğinden (Berthelsen ve Walker 2008; Jeynes, 2007; Shiffman, 2013), cinsiyet değisskenine göre farklılı̆̆ın görülmemesi normal bir durum olarak değerlendirilebilir. Çünkü bu davranış ve etkinlikler tüm çocuklar için ortaktır.

Okul öncesi dönem çocuklarının saldırganlık yönelimi düzeyleri yaşlarına göre farklılık göstermemiştir. İkiz ve Öztürk-Samur'un (2016) çalışmasında da çocukların yaşlarına göre fiziksel ve ilişkisel saldırganlık düzeylerinin farklılaşmadığı sonucuna ulaşılmıştır. Kadan (2010) araştırmasında 2004 ve 2005 doğumlu olan çocukların 2003 doğumlu olan çocuklara göre daha saldırgan olduklarını belirtmiştir. Gülay-Ogelman ve Erten-Sarıkaya (2013) ise okul öncesi eğitim almış çocukların saldırganlık düzeylerinin 6 yaşta düşüş gösterdiği sonucuna ulaşmışlardır. Ersan (2017), 4 yaşındaki çocukların ilişkisel saldırganlık düzeylerinin 5 yaşındaki çocuklara göre anlamlı düzeyde yüksek olduğu sonucuna ulaşmıştır. .̇̉lgili alan yazın incelendiğinde çocukların saldırganlık düzeylerinin yaşlarına göre farklılaşmadığı veya yaşa göre değişkenlik gösterdiği görülmektedir. Tipik gelişim gösteren çocukların bazılarında, özellikle 2-5 yaşlar arasında diğerlerine nazaran daha fazla saldırganlık görülür. Saldırgan davranış erken çocukluk sürecinde belirgin olup orta çocukluk ve adölesanlık dönemlerinde de devam eder ancak şekli, çocuğun gelişimiyle birlikte değişebilir (Ostrov, Ries, Stauffacher, Godlesk Adam ve Mullins, 2008). Bu nedenle ilgili değişken üzerine daha fazla araştırmanın yapılmasına ihtiyaç olduğu söylenebilir.

Okul öncesi dönem çocuklarının annelerinin ilgi düzeyleri çocukların yaşlarına göre farklılaşmamıştır. Anne ilgi düzeyinde farklılaşmanın görülmemesinin nedeni; annelerin çocukları ile yaşları ne olursa olsun her daim ilgilenmelerinden kaynaklanıyor olabilir.

Okul öncesi dönem çocuklarının saldırganlık yönelimi düzeyleri kardeş sayılarına göre farklılık göstermemiştir. Ay’ın (2017) ve İkiz ve Öztürk-Samur'un (2016) araştırmalarında da kardeş sayısı değişkenine göre çocukların fiziksel ve ilişkisel saldırganlık düzeyleri farklılık göstermemiştir. 
Gültekin (2006) yeni doğum sürecinde çocukların artık anne-babaları tarafindan sevilmeyecekleri, ailede istenmeyerek terk edildikleri gibi düşüncelere kapılabileceğini ve sonuç olarak kendilerini değersiz hissedebileceklerini belirtmiştir. Kardeş sahibi olmanın bazen çocuklar üzerinde yıkıcı etkisi olabileceğine dikkat çekmiştir. Bu araştırmada ve söz konusu diğer araştırmalarda kardeş sayısı değişkenine göre çocukların saldırganlık yönelimi düzeylerinde farklılık çıkmaması, kardeşlerin şu anki yaşları ile ilişkili olabilir. Küçük çocuklar yeni doğum sürecinde kardeş kıskançlığı yaşasalar da zaman içerisinde bu duygu ortadan kalkabilmektedir.

Okul öncesi dönem çocuklarının annelerinin ilgi düzeyleri kardeş sayısı değişkenine göre farklılaşmamıştır. Her ne kadar kardeş sayısının anne ilgisinde farklılık oluşturacağı ve kardeş sayısı arttıkça annenin ilgisinde dolaylı olarak azalma görüleceği düşünülse de; araştırmaya katılan annelerin yaklaşık \%68'inin tek çocuk ya da iki çocuk sahibi olduğu sonucundan hareketle farklılık çıkmamasının olası bir sonuç olduğu düşünülebilir.

Okul öncesi dönem çocuklarının saldırganlık yönelimi düzeyleri doğum sırasına göre farklılık göstermemiştir. Ay’ın (2017); İkiz ve Öztürk-Samur'un (2016) ve Şen’in (2009) çalışmalarında çocukların fiziksel ve ilişkisel saldırganlık düzeyleri doğum sıralarına göre farklılaşmamıştır. Söz konusu araştırma sonuçları, bu araştırma sonucu ile örtüşmektedir. Nitekim bu sonuç doğrultusunda çocukların kendilerinden büyük veya küçük kardeşlerinin olmasının saldırganlık yönelim düzeyi üzerinde etkisinin olmadığı söylenebilir. Sosyal öğrenme teorisinin temel kavramlarından biri de model alma ile öğrenmedir. Yine Bandura bireylerin her şeyi doğrudan öğrenmesine gerek olmadığını, başkalarının deneyimlerini gözlemleyerek birçok şeyi öğrenebileceklerini belirtmiştir (Akt. Demirbaş ve Yağbasan, 2005). Sosyal öğrenme teorisi göz önünde bulundurularak; davranış şekillenmesinde, yaş farkı gözetmeksizin çocukların evde etkileşime girebilecekleri, model alacakları ve yakın ilişkiler kurabilecekleri bireylerin bulunmasının önemli olduğu yorumu yapılabilir.

Okul öncesi dönem çocuklarının annelerinin ilgi düzeyleri çocukların doğum sırasına göre farklılaşmamıştır. Çocukların doğum sıralarına baktığımızda yaklaşık \%86'sının ilk ve ikinci çocuk olduğu görülmektedir. Bundan dolayı ilgi düzeylerinde de kardeş sayısında olduğu gibi farklılık görülmemiş olabilir. Anneler her ne kadar inkar etse de kardeşler arasında gözde çocukları olduğu yapılan çalışmalarda belirtilmiştir. Bu çalışmalarda annelere yetişkin çocukları ile ilgili sorular sorulmuş ve gözde çocuklarının yaşları ilerlediğinde bile değişmediği sonucuna ulaşılmıştır (Suitor ve Pillemer, 2000; Suitor ve Pillemer, 2006; Suitor, Sechrist ve Pillemer, 2007; Suitor, vd., 2016). Yapılan bir çalışmada ise doğum sırası; annelerin gözde çocuk seçiminde ve çocuklarından birini 
duygusal olarak kendilerine daha yakın hissetme durumlarında etkili olmuştur. Çalışma sonucuna göre; büyük ve küçük çocukların gözde çocuk olma durumu, ortanca çocuklara göre daha fazladır (Suitor ve Pillemer, 2007). Farklılı̆̆ın görülmemesinin bir nedeni de gözde çocuk olma ile ilişkilendirilebilir.

Okul öncesi dönem çocuklarının saldırganlık yönelimi düzeyleri anne yaşına göre farklılık göstermemiştir. Konuya yönelik araştırmalar incelendiğinde anne yaşı değişkeni ile küçük çocukların saldırganlık yönelim düzeylerinin birlikte ele alındığı herhangi bir araştırmaya rastlanmamıştır. Eratay'ın (2011), okul öncesi çocukların davranış problemlerini incelediği bir araştırmasında çalışmaya katılan annelerin yaşı ile çocuklarda görülen problemli davranışlar arasında bir ilişki bulunmamıştır. Bu araştırma sonucu ile sözü edilen araştırmanın sonucu benzerlik göstermektedir. Anne yaşına göre çocukların saldırganlık yönelim düzeylerinde farklılık görülmemesinin nedeni, annelerin yaşları fark etmeksizin çocuklarında görülebilecek sorunlu davranışları önlemeye yönelik benzer tutumlar benimseyip sergilemeleri olarak düşünülebilir.

Okul öncesi dönem çocuklarının annelerinin ilgi düzeyleri anne yaşına göre farklılaşmamıştır. Bunun nedeni, anne ilgisinin içgüdüsel olması ve hangi yaşta olursa olsun anneliğe yönelik olumlu tutumun gösterilmesi olabilir. Nitekim Şener ve Karacan (1999), anneliğin içgüdüsel olduğunu ve hangi yaşta anne olunursa olunsun, anneliğe yönelik tutumun olumlu olabileceğini belirtmişlerdir. Anneliğe yönelik gösterilen olumlu tutumun, çocuğa gösterilen ilgiyi de olumlu yönde etkileyeceği düşünülmektedir. Yine yapılan bir çalışmada annelerin ilk ebeveyn olma yaşlarına göre ebeveynliğe yönelik yeterlilik, ilgi, doyum ve genel tutum puan ortalamaları arasında fark görülmemiştir (Seçer, Çeliköz ve Yaşa, 2008). Bu nedenle anne yaşına göre ilgi düzeylerinde fark çıkmamış olabilir.

Okul öncesi dönem çocuklarının saldırganlık yönelim düzeyleri annelerin eğitim durumlarına göre farklılık göstermemiştir. Uysal ve Dinçer (2013) ve Ay (2017) araştırmalarında anne eğitim durumuna göre çocukların saldırganlık düzeylerinin değişmediğini bulmuştur. Çiftci-Topaloğlu (2013) ise ilkokul mezunu annelerin çocuklarının lise mezunu annelerin çocuklanına göre daha yüksek düzeyde saldırgan olduklarını belirlemiştir. Aynı araştırmada ortaokul mezunu annelerin çocuklarının saldırganlık düzeyleri, lise ve üniversite mezunu annelerin çocuklarına göre daha yüksek bulunmuştur. Kadan (2010) araştırmasında annelerin eğitim seviyelerinin düştükçe çocuklarının saldırganlık düzeylerinin arttığını belirlemiştir. Görüldüğü üzere alan yazında söz konusu değişkene göre farklı araştırma sonuçları bulunmaktadır. Bu durumun nedeni araştırmalardaki çalışma gruplarının içinde bulundukları sosyokültürel çevre ile ilgili olabilir. Yapılan bu araştırmada annelerin yakın çevreleri ile olan ilişkileri, eğitim durumları arasındaki farklılıkları 
azaltıcı yönde etki etmiş olabilir. Bu da çocukların saldırganlık yönelim düzeylerinin anne eğitim durumuna göre değişkenlik göstermemesine neden olarak gösterilebilir.

Okul öncesi dönem çocuklarının annelerinin eğitim düzeyine göre çocuklarına yönelik ilgi düzeylerini gösteren sonuçlar doğrultusunda, üniversite mezunu annelerin ilkokul ve ortaokul mezunu annelere göre çocuklarıyla daha fazla ilgilendikleri sonucuna ulaşılmıştır. Annenin eğitim düzeyinin yüksekliğinin ve çalışma durumunun ebeveynliğe yönelik ilgisinin artmasında etkili olacağ1 araştırmacılar tarafindan belirtilmiştir (Seçer, Çeliköz ve Yaşa, 2008). Bu nedenle de eğitim düzeyinin artmasına bağlı olarak annelerin çocuklarına olan ilgilerinin de arttığı söylenebilir.

Okul öncesi dönem çocuklarının saldırganlık yönelimlerinin anne çalışma durumu değişkenine göre incelenmesi sonucu elde edilen bulgular, çalışan annelerin çocuklarının çalışmayan annelerin çocuklarına göre daha saldırgan olduklarını göstermiştir. Kadan'ın (2010) ise araştırmasında annesi çalışmayan çocukların annesi çalışanlara göre daha saldırgan oldukları belirtilmiştir. İlgili araştırma sonuçları, bu araştırma sonucuyla örtüşmemektedir. Bunun nedeni çocukların saldırganlık düzeyleri üzerinde etkili olan farklı etmenler olabilir.

Okul öncesi dönem çocuklarının annelerinin ilgi düzeyleri annenin çalışma durumuna göre farklılık göstermemiştir. Çalışan annelerin çocuklarına ayıracakları vaktin çalışmayan annelere göre az olmasından dolayı çocuklarıyla geçirdikleri zamanın nitelikli olması önemlidir (Tarhan, 2011:56). Çalışan annelerin genelde çocuklarıyla daha az ilgilenebildikleri düşünülse de bu açı̆̆1 çocuklarıyla kaliteli zaman geçirerek kapatmış olmaları muhtemel bir sonuçtur. Yine çalışmayan annelerin çalışan annelere göre genelde daha fazla çocuk sahibi olmalanı ve ev işlerine çalışan annelere göre daha fazla önem vermeleri de ilgi düzeylerini etkilemiş ve çalışan annelere yakın bir sonuca ulaşılmasına; dolayısıyla farklılık çıkmamasına neden olmuş olabilir.

Okul öncesi dönem çocuklarının saldırganlık yönelimleri ile annelerinin ilgi düzeylerinin incelendiği araştırma sonuçlarına göre;

- Okul öncesi dönem çocuklarının saldırganlık yönelimleri ile anne ilgileri arasında düşük düzeyde ve negatif yönde anlamlı bir ilişki bulunmuştur.

- Cinsiyet değişkenine göre saldırganlık yönelim düzeylerinde, erkek çocukların saldırganlık yönelimlerinin kız çocuklarına göre daha yüksek düzeyde olduğunu sonucuna ulaşılmıştır. Anne ilgileri ise cinsiyete göre farklılaşmamaktadır.

- Yaş, kardeş sayısı, doğum sırası, anne yaşı değişkenlerine göre çocukların saldırganlık yönelimi düzeyleri ve anne ilgileri farklıllk göstermemiştir. 
- Anne eğitim düzeyi değişkenine göre çocuklarının saldırganlık yönelim düzeyleri farklılık göstermezken, anne ilgileri arasında farklılık gözlemlenmiştir.

- Okul öncesi dönem çocuklarının saldırganlık yönelimleri anne çalışma durumu değişkenine göre farkl1lık göstermiş olup, annelerinin ilgi düzeyleri annenin çalışma durumuna göre farkl111k göstermemiştir.

\section{Öneriler}

- Çocukların saldırganlık yönelimleri ile anne ilgi düzeyi birbiriyle ilişkili olduğu için annelere konu hakkında seminerler düzenlenip bilgilendirmeler yapılabilir. Hatta geliştirilecek eğitim programlarına anneler de dahil edilebilir. Böylece olumlu anne-erkek çocuk ilişkileri geliştirilerek toplumun erkek çocukların saldırgan davranış sergilemelerine yönelik benimsediği tutumların değişimi için birtakım temellerin atılması sağlanabilir.

- Konuya yönelik olarak yapılacak sonraki araştırmalarda çocukların kardeşlerinin yaşlarına göre saldırganlık yönelim düzeyleri incelenebilir.

- İlkokul başlangıcı, yeni kardeş veya belli kritik dönemlerin içinde bulunduğu yaş aralıklarında yapılacak çalışmalarla anne ilgilerinin yaşa göre farklılaşma durumu incelenebilir.

- Anne ilgi düzeyleri, gruplarda sayı olarak eşit ya da yakın olacak şekilde kardeş sayısı değişkeni içeren çalışmalar yapılarak incelenebilir.

- Saldırgan davranışların azaltılmasına yönelik eğitim programları hazırlanırken; anne babanın ya da toplumun cinsiyete bağlı yaklaşımındaki farklılı̆̆1 azaltmaya yönelik farkındalık yaratılmasına da önem verilebilir.

\section{KAYNAKÇA}

Alisinanoğlu, F. ve Kesicioğlu, O.S. (2010). Okul öncesi dönem çocuklarının davranış sorunlarının çeşitli değişkenler açısından incelenmesi (Giresun ili örneği). Kuramsal Ë̆itimbilim, 3 (1), 93110.

Anderson, K.J. \& Minke, K.M. (2007). Parent involvement in education: Toward an understanding of parents' decision making. The Journal of Educational Research, 100 (5), 311-323.

Ay, H. (2017). Okul öncesi dönemi çocuklarmmn saldirganlık davranıslarmm anne ve ögretmen görüslerine göre incelenmesi. (Yayımlanmamış yüksek lisans tezi). Mehmet Akif Ersoy Üniversitesi Eğitim Bilimleri Enstitüsü, Burdur.

Aydın, H.B. (2004). Çocuk ruh sağglğ̆. İstanbul: Morpa Kültür Yayınları. 
Bacacı Varoğlu, D. (2001). Örgütsel yaşamda toplumsal cinsiyet rolleri. (Der. S. Güney). İstanbul: Nobel Yayın Dağıtım.

Bay-Hinitz, A.K. (2001). Prescribing games to reduce aggression in children. (Eds: C.Schaefer \& S. E. Reid). In: (Game Play Therapeutic Use of Childhood Games (2nd ed., pp. 366-383). New York: NY: John Wiley and Sons, Inc.

Berthelsen D. \& Walker, S. (2008). Parent involvement in their children's educations. Family Matters, 79, 34-41.

Bridge, H. (2001), Increasing parental involvement in the preschool curriculum: what an action research case study revealed. International Journal of Early years Education, 9(1), 6-21.

Bonica, C., Arnold, D.H., Fisher, P.H., Zeljo, A. \& Yershova, K. (2003). Relational aggression, relational victimization and language development in preschoolers. Social Development, 12 (4), 551-562.

Chen, X., Wang, L., Chen, H. \& Liu, M. (2002). Noncompliance and child-rearing attitudes, as predictors of aggressive behavior: a longitudinal study in Chinese children. International Journal of Behavioral Development, 26 (3), 225-233.

Crnic, K.A., Gaze, C. \& Hoffman, C. (2005). Cumulative parenting stress across the preschool period: Relations to maternal parenting and child behaviour at age 5. Infant and Child Development, 14, 117-132.

Çiftci-Topaloğlu, Z. (2013). 4-5 yas çocuklarmm sosyal yetkinlik, salderganhk, kayg düzeyleri ile annebabalarmmn ebeveyn özyeterliği algısı arasindaki ilişskilerin incelenmesi. (Yayımlanmamış yüksek lisans tezi). Pamukkale Üniversitesi Eğitim Bilimleri Enstitüsü, Denizli.

Demirbaş, M. ve Yağbasan, R. (2005). Sosyal öğrenme teorisine dayalı öğretim etkinliklerinin, öğrencilerin akademik başarılarının kalıcıllğına olan etkisinin incelenmesi. Abant İzet Baysal Üniversitesi Ĕ̈itim Fakültesi Dergisi, 5(1), 161-180.

Dever, A. ve Bulut, E. (2017). Beden eğitimi ve spor yüksekokulu öğrencilerinin saldırganlık düzeylerinin araştırılması: Ordu Üniversitesi örneği. Munzur Üniversitesi Sosyal Bilimler Dergisi, 5 (10), 45-56.

Dursun, A. (2010). Okul öncesi dönemdeki çocuklarm davranıs problemleriyle anne-baba tutumlar arasindaki ilişkinin incelenmesi. (Yayımlanmamış yüksek lisans tezi). Dokuz Eylül Üniversitesi, İzmir.

Eratay, E. (2011). Okul öncesi çocuklarında davranış problemleri. e-Journal of New World Sciences Academy, 6 (3), 2347-2362).

Erbaş, D., Kırcali-İftar, G. ve Tekin-İftar, E. (2004). Işslevsel değerlendirme (davranıs sorunlarryla başa cıkma ve uygun davranıslar kazandırma süreci). Ankara: Kök Yayıncilık.

Eroğlu, S.E. (2009). Saldırganlık Davranışının Boyutları ve İlişkili Olduğu Faktörler: Lise ve Üniversite Öğrencileri Üzerine Karşılaştırmalı Bir Çalışma. Selçuk Üniversitesi Sosyal Bilimler Enstitïsü Dergisi. 21, 205-221. 
Ersan, C. (2017). Okul öncesi dönem çocuklarnm saldirganlık düzeylerinin duygu ifade etme ve duygu düzenleme açısından incelenmesi. (Yayımlanmamıș doktora tezi). Pamukkale Üniversitesi Eğitim Bilimleri Enstitüsü, Denizli.

Flouri, E. (2006). Parental interest in children's education, children's self-esteem and locus of control, and later educational attainment: Twenty-six-year follow-up of the 1970 British birth cohort. British Journal of Educational Psychology, 76, 41-55.

Freedman, J.L., Sears, D.O. \& Carlsmith, J.M. (1998). Sosyal psikoloji. (Çev: A. Dönmez). Ankara: İmge.

Fromm, E. (1993). Frend düşüncesinin büyü̈klüğ̈̈ ve sinırları. (Çev: A. Arıtan). İstanbul: Arıtan Yayınları.

Gülay, H. (2008). 5-6 yas çocuklarna yönelik akeran ilişkileri ölçeklerinin geçerlik güvenirlik çalısmalar ve akeran iliskilerinin ceșitli değiskeenler açısından incelenmesi. (Yayımlanmamıș doktora tezi). Marmara Üniversitesi Eğitim Bilimleri Enstitüsü, İstanbul.

Gülay Ogelman, H. ve Erten Sarıkaya, H. (2013). Okul öncesi eğitimi almış çocukların akran ilişskileri değişkenlerinin 5 ve 6 yaşta incelenmesi: İki yıllık boylamsal çalışma. International Periodical For The Languages, Literature and History of Turkish or Turkic. 8 (8), 1859-1871.

Gültekin, M. (2006). Okul öncesinde duygu ve davranıss sorunlar. İstanbul: Nesil Yayınları.

İkiz, S. ve Öztürk-Samur, A. (2016). Okul öncesi dönem çocuklarında fiziksel ve ilişkisel saldırganlığın ebeveyn tutumları açısından incelenmesi. Mustafa Kemal Üniversitesi Sosyal Bilimler Enstitüsü Dergisi, 13 (35), 159-175.

İnan, M., Karagözoğlu, C. ve Şimşek, Ö. (2014). 7 yaş çocuklarında hareketli oyunların saldırganlık davranışları üzerine etkileri. Pegem Eğitim ve Ögr̆etim Dergisi, 4 (1), 47-58.

Jarvinen, L.K. (2001). Agressive behaviour and social problem-solving strategies: A review of the findings of a seven-year follow-up from childhood to late adolescence. Criminal Behaviour and Mental Healt, 11, 236-250.

Jeynes, W.H. (2007). The relationship between parental involvement and urban secondary school student academic achievement: A meta-analysis. Urban Education, 42 (1), 82-110.

Kadan, G. (2010). Okul öncesi dönem cocuklarnda (4-6 yass) saldırganlık davranısın etkileyen faktörlerin çesitli değ̈iskenlere göre incelenmesi. (Yayımlanmamış yüksek lisans tezi). Marmara Üniversitesi Eğitim Bilimleri Enstitüsü, İstanbul.

Karasar, N. (2013). Bilimsel araștırma yöntemi. Ankara: Nobel Akademik Yayınc1lik.

Kartal, G.K. (2014). Okul öncesi eğitim kurumuna devam eden çocuklarm davranı̧s sorunlar ile annelerin evlilik uyumlar arasındaki ilișkinin incelenmesi. (Yayımlanmamıs yüksek lisans tezi). Haliç Üniversitesi Sosyal Bilimler Enstitüsü, İstanbul.

Kaynak, K.B., Kan, A. ve Kurtulmuş Z. (2016). 36-72 aylık çocuklara yönelik “saldırganlık yönelim ölçeği” geliştirme çalışması. Turkish Studies, 11 (3), 1457-1474. 
Kaymak Özmen, S. (2004). Aile içinde öfke ve saldırganlığın yansımaları. Ankara Üniversitesi Eğitim Bilimleri Fakültesi Dergisi. 37 (2), 27-39.

Köknel, Ö. (1996). Bireysel ve toplumsal şiddet. İstanbul: Altın Kitaplar.

Köse, S. K. (2008) Korelasyon ve regresyon analizi http://www.scribd.com/doc/2066772/korelasyonanalizi. Erișim Tarihi: 15.07.2019

Kutlu, H. (2014). Okul öncesi kurumuna devam eden 5 yaş grubu çocuklarn saldrrgan eğilimleri üzerinde ebeveyn tutumunun etkisinin psikanalitik kuram çerçevesinde incelenmesi. (Yayımlanmamış yüksek lisans tezi). Maltepe Üniversitesi Sosyal Bilimler Enstitüsü, İstanbul.

Marcus, R.F. \& Kramer, C. (2001). Reactive and proactive aggresion: Attachment and social competence predictors. The Journal of Generic Psychology, 162 (3), 260-275.

McAllister, B. \& Schmid, A.P. (2011). Theories of terrorism. The Routledge Handbook of Terrorism Research, (Ed. Alex P. Schmid). (In: 201-271). New York: Routledge.

Miller, A.J. (2002). Çocuklarda depresyon. (Çev: M. Iş1k). İstanbul: Özgür Yayınları.

Osterman, K., Björkqvist, K., Lagerspetz, K., Charpentier, S., Caprara G. \& Pastorelli, C. (1999). Locus of control and three types of aggression. Aggressive Behavior, 25, 61-65.

Ostrov, J. M., Ries, E. E., Stauffacher, K., Godleski, S. A., \& Mullins, A. D. (2008). Relational aggression, physical aggression and deception during early childhood: A multimethod, multi- informant short-term longitudinal study. Journal of Clinical Child \& Adolescent Psychology, 37(3), 664-675.

Öngören-Özdemir, S. ve Tepeli, K. (2016). Okul öncesi öğretmenlerinin saldırgan davranışlarla baş etme stratejilerinin incelenmesi. Ahi Evran Üniversitesi Kurşsehir Eğitim Fakültesi Dergisi, 17 (2), $51-70$.

Özbey, S. (2010). Okul öncesi çocuklarda uyum ve davranış problemleriyle başa çıkmada ailenin rolü. Aile ve Toplum, 6 (22), 9-18.

Özbey, S. ve Alisinanoğlu, F. (2009). Okul öncesi eğitim kurumuna devam eden 60-72 aylık çocukların problem davranışlarının bazı değişkenlere göre incelenmesi. Uluslararası Sosyal Arastirmalar Dergisi, 2 (6), 493-517.

Özen, G. (2010). Karşıt olma ve karşıt gelme bozukluğu olan çocuklarn rubsal işleyişlerinin projektif testlerle değerlendirilmesi. (Yayımlanmamış yüksek lisans tezi). İstanbul Üniversitesi Sosyal Bilimler Enstitüsü, İstanbul.

Papalia, D.E., Olds, S.W., Feldman, R.D. \& Gross, D. (2003). Human development. (9 th. edition). USA: McGraw Hill.

Savran, A. G. ve Demiryontan, T. N. (2016). Kadmmn görünmeyen emeği. İstanbul: Yordam Kitap.

Sayın, U. (2014). 48-72 ayllk çocuklardaki saldrganlık davranıslarna müdabale yöntemi olarak ebeveyn eğitim program gelistirilmesi ve etkililiğinin incelenmesi. (Yayımlanmamış doktora tezi). Hacettepe Üniversitesi Sağlık Bilimleri Enstitüsü, Ankara. 
Seçer, Z., Çeliköz, N. ve Yaşa, S. (2008). Okulöncesi eğitim kurumlarına devam eden çocukların annelerinin ebeveynliğe yönelik tutumları. Selçu Üniversitesi Sosyal Bilimler Enstitüsü Dergisi, 19, 413-428.

Shiffman C.D. (2013). The juggling act: Navigating parent involvement in the welfare reform era. Educational Policy, 27 (1), 64-91.

Sucuoğlu, H., Özkal, N., Yıldız Demirtaş, V. ve Güzeller, C.O. (2015). Çocuğa yönelik anne-baba ilgisi ölçeğinin geliştirme çalışması. Abant İzzet Baysal Üniversitesi Eğitim Fakültesi Dergisi, 15 (1), 242-263.

Suitor, J.J., Gilligan, M., Peng, S., Con, G., Rurka, M. \& Pillemer, K. (2016). My pride and joy? Predicting favoritism and disfavoritism in mother-adult child relations. Journal of Marriage and Family, 78, 908-925.

Suitor, J.J. \& Pillemer, K. (2000). Did mom really love you best? Exploring the role of within-family differences in developmental histories on parental favoritism. Motivation and Emotion, 24, 104-19.

Suitor, J.J. \& Pillemer, K. (2006). Choosing daughters: Exploring why mothers favor adult daughters over sons. Sociological Perspectives, 49 (2), 139-161.

Suitor, J.J. \& Pillemer, K. (2007). Mothers' favoritism in later life: The role of children's birth order. Research on Aging, 29 (1), 32-55.

Suitor, J.J., Sechrist, J. \& Pillemer, K. (2007). When mothers have favorites: Conditions under which mothers differentiate among their adult children. Canadian Journal on Aging, 26, 8599 .

Şen, M. (2009). 3-6 yaş grubu çocuklarn sosyal davranışlarmm bą̧ değğskenler açısından incelenmesi. (Yayımlanmamış doktora tezi). Hacettepe Üniversitesi Sağlık Bilimleri Enstitüsü, Ankara.

Şener, Ş. ve Karacan, E. (1999). Anne-bebek-çocuk etkileşiminde olumlu ve olumsuz özellikler. Ben Hasta Değilim Çocuk Sağgl̆̆g ve Hastahklarmm Psikososyal Yönü. (Ed: Aysel Eksşi), İstanbul: Nobel Tip Kitabevleri.

Tarhan, N. (2011). Aile Okulu. (14. Baskı). İstanbul: Timaş Yayınları.

Thomas, S. P. (2003). Men's anger: a phenomenological exploration of its meaning in a middleclass sample of american men. Psychology of Men and Masculinity, 4 (2), 163-175.

Uysal, H. ve Dinçer, Ç. (2013). Okul öncesi dönemde karşılaşılan fiziksel ve ilişkisel saldırganlı̆̆ın bazı değisskenler açısından incelenmesi. Eğitim ve Bilim, 38 (169), 328-345.

Yıldız, A.S. (2004). Ebeveyn tutumları ve saldırganlık. Polis Bilimleri Dergisi, 6 (3-4), 131-150.

Yizhen, Y., Junxia, S., Yan, H. \& Jun, W. (2006). Relationship between family characteristics and aggressive behaviors of children and adolescents. Journal of Huąhong University of Science and Technology (Medical Sciences). 26 (3), 380-383. 